\title{
Morphology and taxonomic significance of the otoliths of some bathypelagic Anguilloidei and Saccopharyngoidei from the Sargasso Sea
}

\author{
T. Hecht ${ }^{1} \&$ S. Appelbaum ${ }^{2}$ \\ ${ }^{1}$ Department of Ichthyology and Fisheries Science, Rhodes University; Grahamstown, \\ South Africa \\ ${ }^{2}$ Zoologisches Institut und Museum der Universität Hamburg; \\ Martin-Luther-King-Platz 3, D-2000 Hamburg 13, Federal Republic of Germany
}

\begin{abstract}
The sagittal otoliths of seven anguilliform species belonging to the families Nemichthyidae, Serrivomeridae and Eurypharyngidae are described and illustrated, and a key for their identification is provided. Although the leptocephali of the various fish species treated here have similar otoliths, some species develop specific otolith characteristics during the adult stage. The shape as well as the ratio of fish length to otolith length ratio in adults may serve as a taxonomic aid. Since the sagittae of these fishes can be used for specific identification, the digested remains of prey in the stomachs and guts of predators can be identified.
\end{abstract}

\section{INTRODUCTION}

This is apparently the first report on the comparative morphology of the otoliths of deep-sea snipe eel. As these fishes have a wide distribution in the Atlantic, Pacific and Indian Oceans (Nelson, 1976), information on the morphology of their otoliths could serve as an additional criterion for the systematics of this group. Post \& Hecht (1977) briefly list some of the factors which could possibly have been responsible for the lack of such studies. However, more attention is currently being paid to the otoliths of recent fishes. In the following we demonstrate their use as an additional taxonomic character in seven anguilliform species (for historical review of otolith research see Hecht, 1978).

\section{MATERIAL AND METHODS}

The fishes examined in the present study were collected on board F. R. V. "Anton Dohrn" during the Eel Expedition to the Sargasso Sea from March through May 1979, (Tesch, 1982). The otoliths of the following anguilliform species are described:

Family Nemichthyidae: Nemichthys scolopaceus (Richardson) (n=3) SL (standard length) $=212,374,703 \mathrm{~mm}$. $N$. curvirostris (Strömman) $(\mathrm{n}=3) \mathrm{SL}=455$, $570,575 \mathrm{~mm}$. Labichthys carinatus (Gill \& Ryder) $(\mathrm{n}=2) \mathrm{SL}=345,567 \mathrm{~mm}$.

Family Serrivomeridae: Serrivomer beani (Gill \& Ryder) ( $\mathrm{n}=37$ ) TL (total length) $=$ leptocephali $28,36,37,46,46$ and 51 ; juveniles $103,110,110 \mathrm{~mm}_{\text {; }}$ adults 122 , 


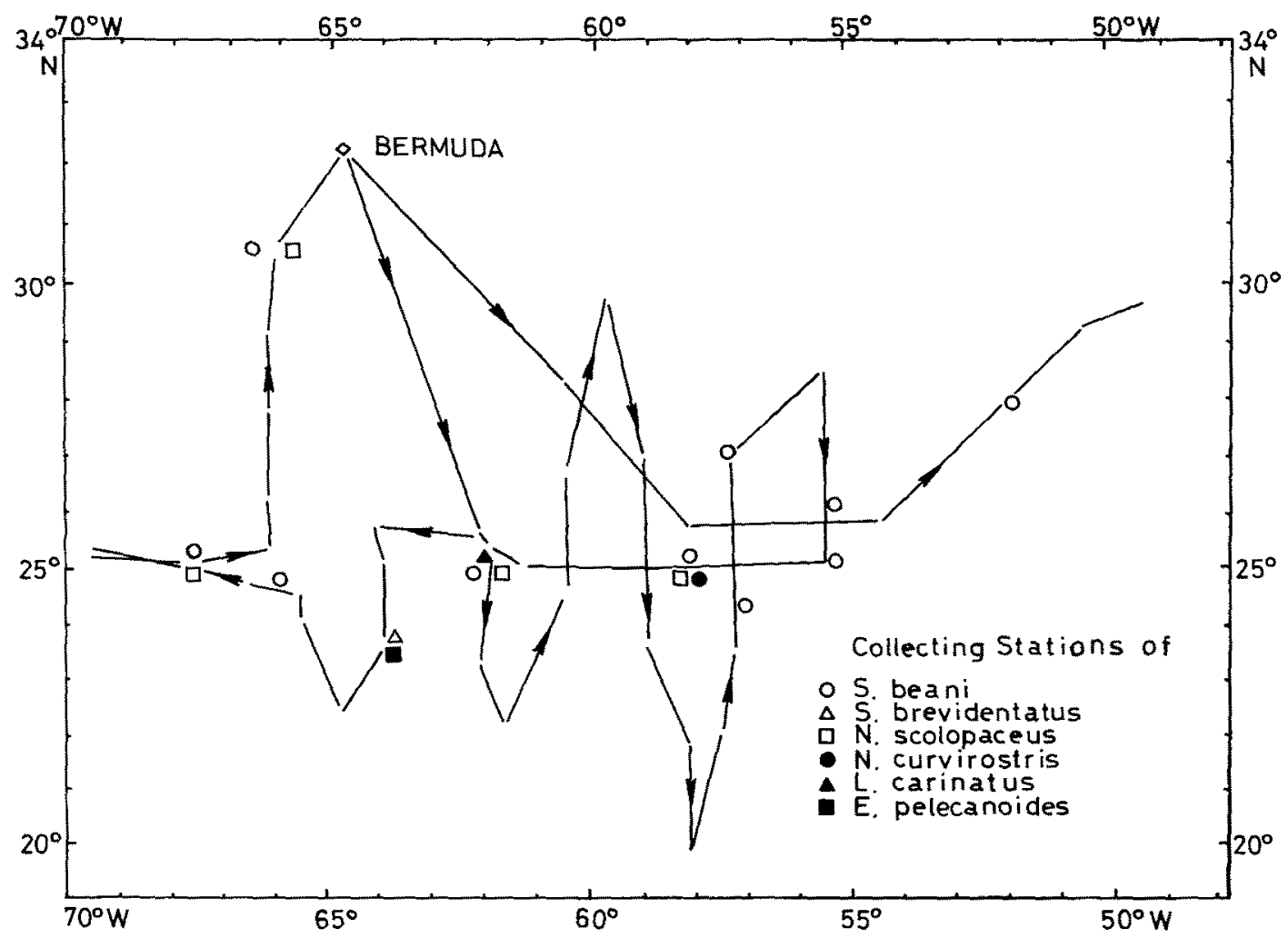

Fig. 1. Route of F. R. V. "Anton Dohrn" during the expedition to the Sargasso Sea (March-May 1979) and the catch localities of various fish species

$160,160,169,185,186,193,210,225,240,254,275,319,325,345,381,387,395,412$, $420,434,512,541,549,563,676,715,732 \mathrm{~mm}$. $S$. brevidentatus (Roule \& Bertin) $(\mathrm{n}=4)$ $\mathrm{TL}=255,316,450,481 \mathrm{~mm}$.

Family Eurypharyngidae: Eurypharynx pelecanoides (Vaillant) $(\mathrm{n}=3)$ $\mathrm{TL}=200,210,676 \mathrm{~mm}$.

The locations at which the various species were caught are shown in Figure 1. Leptocephali were taken at depths of $450 \mathrm{~m}$ and above (Schoth \& Tesch, 1982), while the adults were collected as deep as $1800 \mathrm{~m}$ (Post \& Tesch, 1982). The sagitta were removed either ventrally or laterally from the capsula auditiva and were measured by camera Iucida projections or vernier calipers. Nemichthyid fishes were measured from the tip of the snout to a point marking the beginning of the filament. This has been designated as standard length (SL). All otoliths treated are in the private collection of the senior author.

\section{RESULTS AND DISCUSSION}

Brief descriptions of the sagittae of the various species are presented in the following. 


\section{Family Nemichthyidae (Anguilloidei)}

Nemichthys scolopaceus (Fig. 2 A, B). Otolith generally circular except for oblique anterior margin. Rostrum poorly developed to absent. Antirostrum and excisura ostii absent. Both cristae, superior and inferior absent. Sulcus acusticus clearly defined but not divided into ostium and cauda (homosulcoid). Colliculum undivided (homomorph). Sulcus with slight anterior flare and ostial (i. e. opens only on anterior margin).

$N$. curvirostris (Fig. 2 C). Similar in shape to $N$. scolopaceus otolith but virtually circular. Rostrum, antirostrum and excisura ostii absent. Both cristae absent. Sulcus acusticus ostial and homosulcoid. Homomorph colliculum. Differs significantly from N. scolopaceus in relative size (see remarks on nemichthyid otoliths).

Labichthys carinatus (Fig. 2 D). Larger than Nemichthys otoliths. Shape similar to otolith of $N$. scolopaceus, except for gently lobed anterior margin. Both cristae well developed, extending around entire sulcus. Rostrum and antirostrum absent. Excisura ostii slight. Sulcus ostial and homosulcoid. Colliculum homomorph.

The otoliths of the three nemichthyid species examined here are all very similar, but are distinguishable. The ratio of otolith length to standard fish length (OL:SL) might be a usefull characteristic for the identification of nemichthyid species. The following specific ratios were found: Nemichthys scolopaceus OL:SL $=1: 732, N$. curvirostris $\mathrm{OL}: \mathrm{SL}=1: 1420$, Labichthys carinatus $\mathrm{OL}: \mathrm{SL}=1: 590$.

These OL:SL ratios should not be regarded as fully reliable, however, because relatively few specimens were measured. If more specimens were available, it would probably be possible to calculate reasonably accurate ranges of ratios in order to distinguish these species.

\section{Family Serrivomeridae (Anguilloidei)}

Serrivomer beani (Fig. 2 E, F, G). Typically anguilliform (Hecht \& Hecht, 1978). Generally oval, slightly wider posteriorly. Outer margin: smooth to gently lobed. Sulcus acusticus ostial and homosulcoid. Colliculum homomorph. Rostrum and antirostrum clearly defined as rounded anterior lobes. Excisura occupied by the projection of fused cristae. Sulcus extends into excisural projection (typical of genus Serrivomer).

$S$. brevidentatus (Fig. $2 \mathrm{H}$, I). Shape similar to $S$. beani, virtually indistinguishable except for anterior geometric shape. Rostrum, antirostrum and excisura ostii are more widely separated from each other and are more pointed and prominent than in $S$. beani. As in $S$. beani, the excisural projection is formed by the fused cristae, superior and inferior. Sulcus ostial and homosulcoid. Colliculum homomorph.

The characteristic feature of Serrivomer otoliths is the "excisural projection" between the rostrum and the antirostrum. In general, the otoliths may be described as being "corn" shaped (see Fig. 2 E, F, G, H, I, K). The otoliths of the two species were distinguished according to their anterior geometric structure. They differ from each other as follows:

In $S$. beani rostrum and antirostrum are slightly rounded and nearly equally long. Excisural projection is formed by fusion and anterior elongation of the cristae. An aberrant form of $S$. beani otoliths was also observed (Fig. $2 \mathrm{~K}$ ). Although the otoliths can be recognized as belonging to $S$. beani from the geometric structure of their anterior parts, their posterior portions were squared off rather than rounded. 

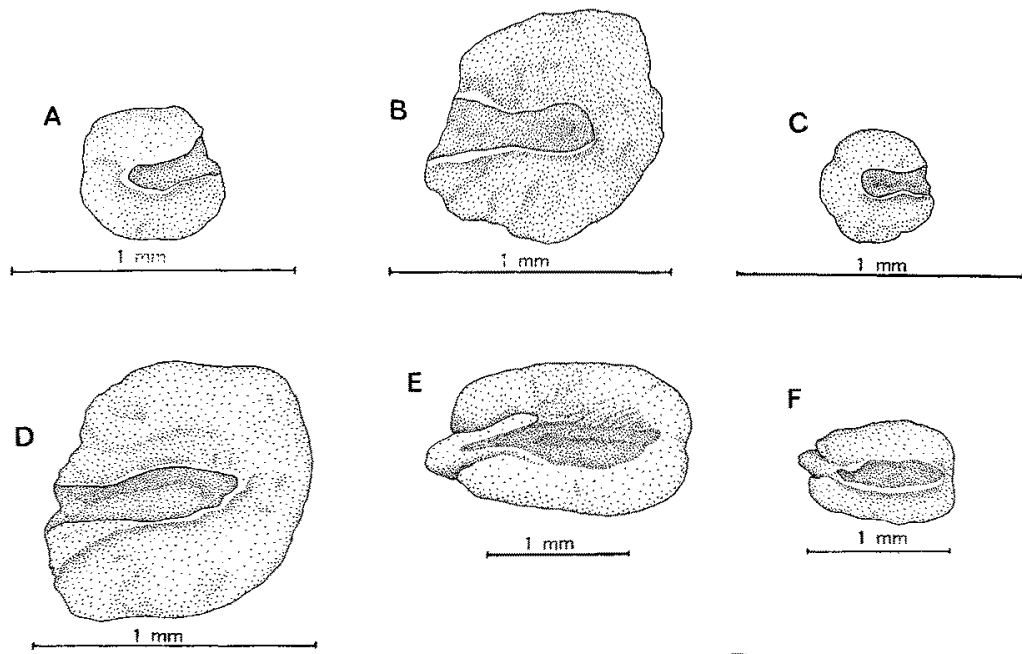

$\mathbf{G}$
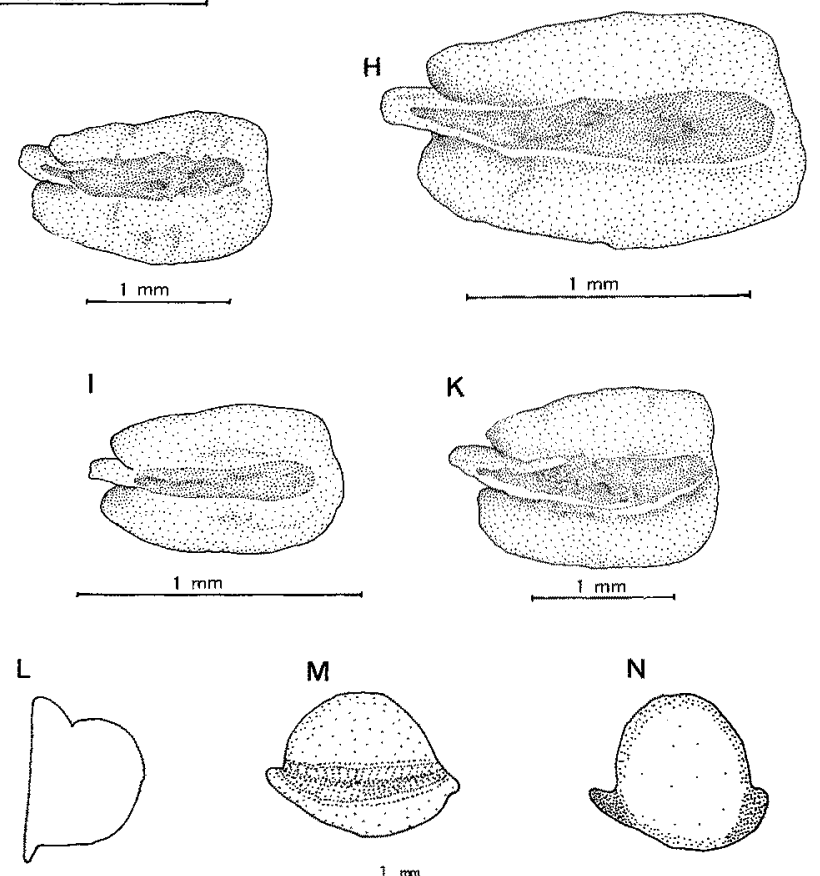

Fig. 2. Sagittal otoliths A and B: Nemichthys scolopaceus, C: Nemichthys curvirostris, D: Labichthys carinatus, E, F, G: Serrivomer beani, H, I: Serrivomer brevidentatus, K: Serrivomer beani, $L, M, N$ : Eurypharynx pelecanoides

In $S$. brevidentatus rostrum and antirostrum are rather pointed and relatively large in relation to the projection. The projection is also formed by the fusion and elongation of the cristae.

The specimens of $S$, beani ranged in length from 18 to $732 \mathrm{~mm}$. They were grouped into $20 \mathrm{~mm}$ size classes, but specimens between 50 and $100 \mathrm{~mm}$ were not available. The 
examination of the otoliths revealed that they grow from an unidentifiable spherical structure into a shape specific for $S$. beani (Fig. 3.). Four ontogenetic stages were identified and are described below:

St age 1 (leptocephali up to $50 \mathrm{~mm}$ in length): The otoliths are spherical with no distinguishing features. The otoliths of several other anguilliform leptocephali, includ-

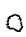

28

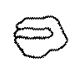

103

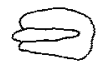

160

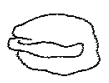

185

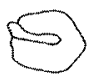

193

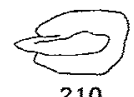

210

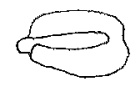

240

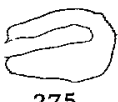

275

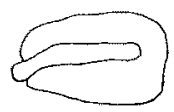

325

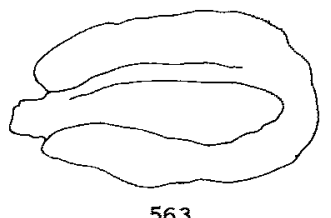

563

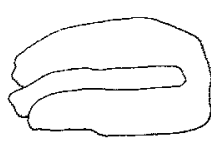

395

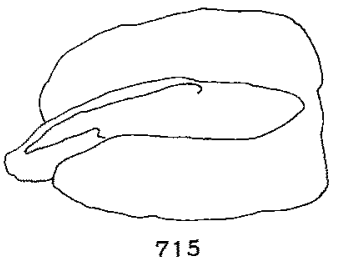

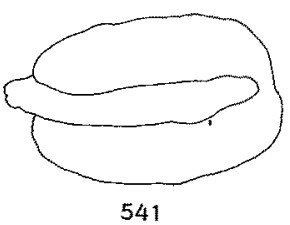

$1 \mathrm{~mm}$

Fig. 3. Ontogenetic development of Serrivomer beani otoliths. Total length ( $\mathrm{mm}$ ) of fishes is indicated below each illustration

ing Xenomystax sp., Ariosoma balearicum, Nemichthys sp., were also removed, - examined and found to be spherical with no distinguishing features. Appelbaum \& Hecht (1978) observed the same otolith developmental pattern in Anguilla anguilla. It is impossible, therefore, to distinguish between anguilliform leptocephalid otoliths. Possibly the metamorphosis from the leptocephalid to the juvenile stage takes place when the fish are in this length range, and the absence of this length group from the catches may, therefore, be due to metamorphosis - dependent migration.

S tage 2 (eels between 100 and $120 \mathrm{~mm}$ in length): The otoliths are oval, and the sulcus acusticus has become recognizable. The projection between the rostrum and antirostrum is still absent. At this stage, the otoliths can be recognized as belonging to anguilliforms (Hecht \& Hecht, 1978).

$\mathrm{S}$ t a g e $3(120-180 \mathrm{~mm}$ in length): The otoliths retain the oval shape and the typical sulcus acusticus of anguilliforms. The "excisural projection" becomes well developed during this stage, which means that the otolith originated from a fish belonging to the genus Serrivomer. 
Stage $4(>180 \mathrm{~mm}$ in length): The otoliths at this stage have assumed the characteristics of $S$. beani, as described above.

The ratio of otolith length to total fish length was calculated and found to be linear: $\mathrm{y}=0.03 \mathrm{x}-0.03 ; \mathrm{x}^{2}=0.97$, where $\mathrm{y}=$ otolith length and $\mathrm{x}=$ total fish length (Fig. 4.). Appelbaum \& Hecht (1978), making a similar analysis of Anguilla anguilla otoliths, found that this ratio becomes linear only after metamorphosis from leptocephalus to the elver stage. This was due to the decrease in body size during metamorphosis, when the otolith continued to grow. Although specimens of $S$. beani between 50 and $100 \mathrm{~mm}$ in length were not available, it is our hypothesis that there is no similar ratio change because of the high correlation coefficient and the subsequent good fit of the calculated least squares regression line to the observed data.

The ratios of otolith length-total fish length of the Serrivomer species were as follows: $S$. beani OL:TL $=1: 365 \pm 45 ; S$. brevidentatus OL:TL $=1: 307$. In contrast to the ratios of the nemichthyid otolith length: fish length, the Serrivomer ratios seem to differ insignificantly and cannot be used for species identification.

The otoliths of $S$. beani were also tested for their suitability as an indicator of the age of the fishes, a practice which is common in fishery biology. For this purpose, the sagittae of two specimens (TL 512 and $715 \mathrm{~mm}$ ) were sectioned to $0.1 \mathrm{~mm}$, fixed on glass slides with DPX mounting fluid and examined. No age rings were evident in these sections.

\section{Family Eurypharyngidae (Saccopharyngoidei)}

Eurypharynx pelecanoides (Fig 2. L-anterior, M-medial and N-lateral). Virtually circular except for anterior and posterior ventral projections. Entire perimeter smooth.

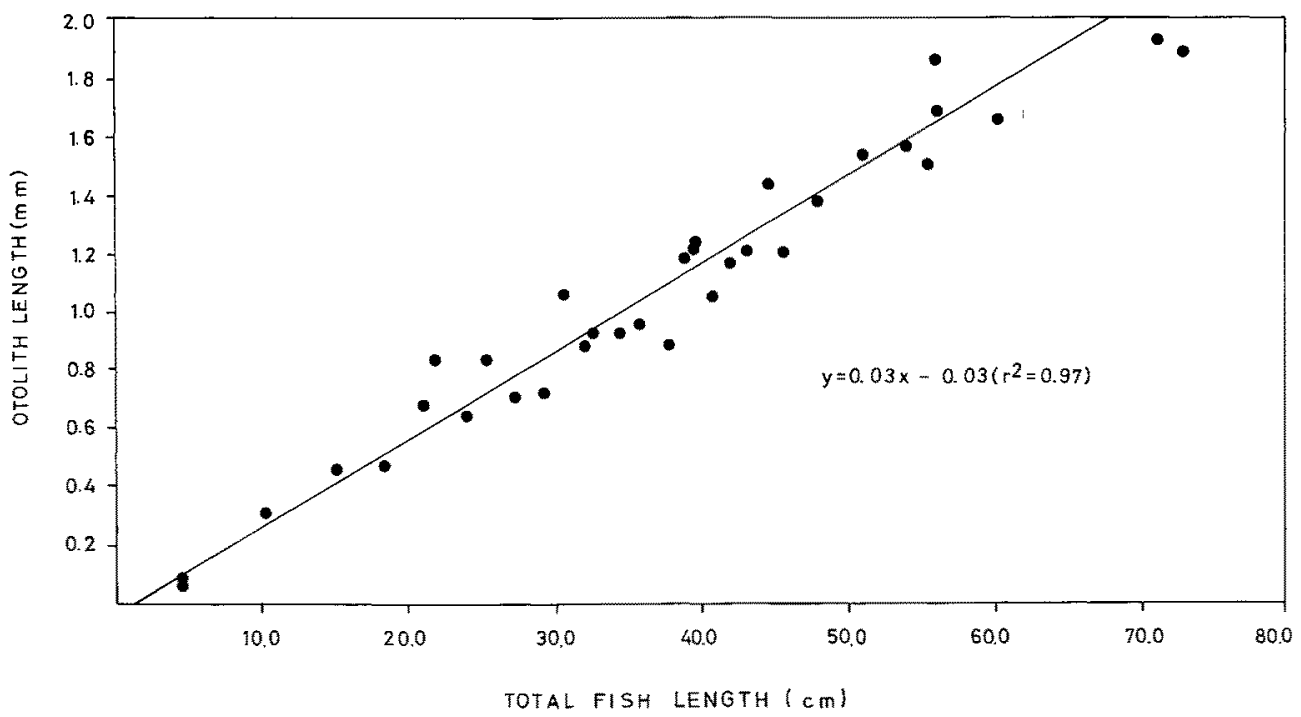

Fig. 4. Relationship between otolith length $(\mathrm{mm})$ and total fish length $(\mathrm{cm})$ in Serrivomer beani 
Sulcus acusticus ostio-caudal (i. e. sulcus opens at anterior as well as posterior margin), homosulcoid. Colliculum homomorph. Rostrum present, antirostrum and excisura ostii absent.

The otoliths of the specimens that were fixed in formalin and later preserved in isopropanol dissolved completely. Otoliths could still be found only in those fishes fixed and preserved immediately in iso-propanol. They are atypical for anguilliforms (Hecht \& Hecht, 1978). The otolith length: fish length ratio was found to be 1:1226.

\section{CONCLUSION}

The present investigation has shown that the specific morphology of the otoliths examined can be used for taxonomic identification of these anguilliform species. However, this can only be done after the stage at which the otoliths attained their specific final shape. The observation of the seven species examined made clear that during metamorphosis and in the larval phase, their otoliths have similar shape and therefore cannot be distinguished from one another. Similar observations were made during previous work on the otoliths of Anguilla anguilla leptocephali (Appelbaum \& Hecht, 1978). After metamorphosis and subsequent development, the otoliths gradually attained a specific shape and could then easily be distinguished. Hempel (1957-1959) observed a similar change in the otolith shape during the first year in the life of the herring.

The otoliths described here can definitely be used for biological and zoogeographical studies of these species. Otoliths are most useful for analysis of predator stomach contents. They remain fairly intact while the fish eaten becomes quickly digested. Moreover, otoliths are occasionally the only remains of prey found in the stomachs of predators (Appelbaum, 1982). The results have also shown that the ratio of otolith length to fish length (OL:SL) can be used for calculation of the size of the prey.

Great effort has been exerted to trace the migration of Anguilla spp. to the Sargasso Sea and to study the biology of these species in their spawning area. Twelve Anguilliformes species were collected during the Sargasso Sea Eel Expedition of 1979 (Post \& Tesch, 1982), but not a single specimen of Anguilla was captured. Among the reasons suggested by the authors, one of the most likely is thought to be that Anguilla individuals migrate in deep layers $(>2000 \mathrm{~m}$ ). Robins et al. (1979) demonstrated the presence of Anguilla sp. on the ocean floor in a deep region of the Atlantic. Post \& Tesch (1982) proposed improved techniques and suggested to make trawling for Anguilla spp. more successfull in future. Investigations of the stomach contents of deep sea predators at suspected eel migration depths would help to provide more information on the mystery of the life history of Anguilla spp. and other Anguilliformes. It is therefore necessary to provide descriptions of otoliths from such species to permit an exact analysis of stomach contents.

\section{KEY FOR IDENTIFICATION OF OTOLITHS}

A key for the identification of the otoliths of the bathypelagic snipe eels considered is presented below. The key refers to the illustrations, and it is valid for adults only.

1. Rostrum and antirostrum absent, sagitta circular.

Sulcus: ostial and homosulcoid. Colliculi homomorph. 
Rostrum and antirostrum present, sagitta not spherical, "corn" shaped. Sulcus ostial and homosulcoid.

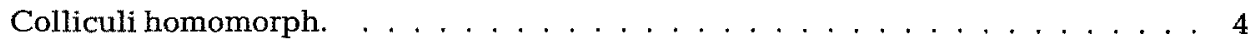

2. Family Nemichthyidae

Cristae not developed . . . . . . . . . . . . . . . . . 3

Cristae well developed . . . . . . . . . . . Labichthys carinatus

3. Otolith generally circular except for oblique

anterior margin . . . . . . . . . . . . . . . Nemichthys scolopaceus

Otolith virtually completely circular . . . . . . . Nemichthys curvirostris

4. Family Serrivomeridae

Rostrum, antirostrum and excisural projection

moderate and rounded . . . . . . . . . . . . . . Serrivomer beani

Rostrum, antirostrum and excisural projection

prominent and pointed

Serrivomer brevidentatus

Acknowledgements. We thank Drs. D. G. Smith, Marine Biochemical Institute, Galveston, Texas (USA), J. E. Smith, Long Beach, California (USA) and F.-W. Tesch, Biologische Anstalt Helgoland, Hamburg (FRG), for their helpful comments on an earlier draft of this manuscript. Thanks is given to Drs. D. G. Smith and J. G. Nielsen for identification of the leptocephali and fish on board. Sincere thanks are also due to A. Hecht for the accurate otolith drawings.

\section{LITERATURE CITED}

Appelbaum, S., 1982. Studies on food organisms of pelagic fishes as revealed by the 1979 North Atlantic Eel Expedition. - Helgoländer Meeresunters. 35, 357-367.

Appelbaum, S. \& Hecht, T., 1978. Otolith length/fish length relationship of leptocephali, elvers and sub-adult (reared) eels, Anguilla anguilla. - Envir. Biol. Fish. 3, 245-247.

Hecht, T. 1978. A descriptive systematic study of the otoliths of the Neopterygean marine fishes of South Africa. Part I. Introduction. - Trans. R. Soc. S. Afr. 43, 191-197.

Hecht, T. \& Hecht, A., 1978. A descriptive systematic study of the otoliths of the Neopterygean marine fishes of South Africa. Part II. The delimitation of teleost orders, some systematic notes and a provisional new phyletic order sequence. - Trans. R. Soc. S. Afr. 43, 199-218.

Hempel, G., 1959. Zum Wachstum der Otolithen bei Jungheringen. - Helgoländer wiss. Meeresunters. 6, 241-259.

Nelson, J. S., 1976. Fishes of the world. Wiley, New York, $416 \mathrm{pp}$.

Robins, C. R., Cohen, D. M. \& Robins, C. H., 1979. The eels, Anguilla and Histobranchus, photographed on the floor of the deep Atlantic in the Bahamas. - Bull. mar. Sci. 29, 401-405.

Post, A. \& Hecht, T., 1977. Results of the Research Cruises of the FRV Walther Herwig to South America XLIX. The otoliths of Diretmus Johnson, 1863 (Osteichthys, Beryciformes, Diretmidae). - Mitt. hamb. zool. Mus. Inst. 74, 165-170.

Post, A. \& Tesch, F.-W., 1982. Midwater trawl catches of adolescent and adult anguilliform fishes during the Sargasso Sea Eel Expedition 1979. - Helgoländer Meeresunters. 35, 341-356.

Schoth, M. \& Tesch, F.-W., 1982. Spatial distribution of 0-group eel larvae (Anguilla sp.) in the Sargasso Sea. - Helgoländer Meeresunters. 35, 309-320.

Tesch, F.-W., 1982. The Sargasso Sea Eel Expedition 1979. - Helgoländer Meeresunters. 35, 263-277. 